\title{
STRUCTURAL CHANGES IN
}

\section{INTERNATIONAL TRADE:}

\section{CAUSE, IMPACT AND RESPONSE}

\author{
by Jan Fagerberg ${ }^{1}$ \\ Centre for Technology, Innovation and Culture, \\ University of Oslo
}

\begin{abstract}
The character of the structural changes in international trade, and the possibility that these might impact countries differently, has been a matter of great concern for many observers from the 1950s onwards. The view that all sectors do not offer the same prospects for growth, and that the specialisation pattern of a country in international trade therefore matters for its economic performance, has also been widespread. This paper analyses the structural changes in international trade between 1965 and 1990, the impact of this on the OECD countries and the ability of these countries to adapt to these changes. It is shown that trade in commodities from industries characterised by high R\&D outlays grew much faster than other trade. But also some goods from industries that do little R\&D displayed high growth (for example clothing). In general, these changes were most favourable for the large and medium-sized countries of the OECD area (high income). Small countries, and low-income countries, benefited much less. There were striking differences across countries in the ability to adapt to these changes. The large rich countries (USA, Japan) and some of the low-income countries showed good adaptability, while many others failed. This holds, for instance, for all the small, high-income countries. It is shown that this to a large extent may be explained by the failure of these countries to carve out sustainable niches for themselves in electronics, the most fast-growing part of world trade during this period.
\end{abstract}

\footnotetext{
${ }^{1}$ This paper is produced as part of the "Globalization program" at the Centre for Technology, Innovation and Culture, University of Oslo. It draws on earlier work carried out as part the "Nordic Economic Policy Project". Financial support from the Norwegian Research Council and Nordic Social Science Cooperation Council (NOS-S) is gratefully acknowledged.
} 


\section{Introduction}

The character of the structural changes in international trade, and the possibility that these might impact countries differently, has been a matter of great concern for many observers from the 1950s onwards. The view that all sectors do not offer the same prospects for growth, and that the specialisation pattern of a country in international trade therefore matters for its economic performance, has also been widespread. For instance, this view appears to have played an important role in the design of the industrial and trade policies of Japan and the socalled high-performing Asian economies in the post war period.

Although widespread this view is not uncontroversial among economic theorists. In fact, until recently traditional neo-classical theory did not attach much importance to trade as a growth-promoting factor. ${ }^{2}$ Following the standard neo-classical approach to growth it did not really matter whether you sold your goods at home or abroad. As for trade, the so-called factor proportion theory postulated that there were some gains from trade through increased specialisation in sectors using intensively the factors with which countries were relatively well equipped. But these gains were essentially of an once and for all nature, and empirical work on trade based on this perspective indicated that these gains were rather small (Robson 1987). Keynesian theories, in contrast, attached a lot of importance to the link between trade and growth. Export demand was considered as an autonomous force that propelled growth (through various multipliers). Anything that could raise export demand would also raise growth (Beckerman 1962, Kaldor 1970). However, the composition of exports also matters following this approach, because demand conditions tend to be more favourable for some types of products than others (Thirlwall 1979, Kaldor 1981). As a consequence, countries that

\footnotetext{
${ }^{2}$ For an overview of the literature on trade and growth, see Dowrick (1997).
} 
happen to produce products that are in high demand internationally may receive a growth bonus, while those specialised in lagging industries may suffer.

The link between trade-specialisation and growth has also been emphasised by a more recent literature that focuses on the roles of $R \& D$, learning and "increasing returns to scale" for economic growth (Lucas 1988, Dosi Pavitt and Soete 1990 and Grossman and Helpman 1991). For instance, Lucas (1988) assumes large differences across sectors in the scope for technological progress (learning). Hence, countries that specialise in the technologically progressive industries (high-tech industry) may experience faster growth than those that don't. Thus, following this approach, the ability to change the pattern of specialisation towards the technologically most progressive industries enters as important factor behind economic performance. However, because of the cumulative character of technological progress, existing patterns of specialisation will tend to be reinforced through time. Hence, changing the received pattern of specialisation may not be so easy (and may require various types of policy interventions to succeed). A similar conclusion may be reached from a perspective that emphasises the importance of $R \& D$ and spillovers for growth and trade (see Grossman and Helpman 1991). Countries that devote a large share of their resources to R\&D, and countries with large domestic markets, will - according to this perspective - be more likely than others to specialise in high-tech industry and grow faster. However, the outcome also depends on the geographical reach of spillovers. ${ }^{3}$ If spillovers are national rather than global in scope, a "lock in" situation may occur, where small initial differences lead to a divergence in specialisation patterns and growth. As in the Lucas model discussed above, this is a situation in which policy interventions may have a large impact.

\footnotetext{
${ }^{3}$ Little is known for sure on the geographical reach of spillovers. Some studies suggest that these often are rather local in nature, i.e., that proximity is an important factor (Jaffe et al. 1993, Maurseth and Verspagen 1999). Arguably, to the extent that presence in foreign markets is required to benefit from technology flows, trade may enhance growth (Coe and
} 
Hence, following these new theoretical developments, the concern for the relationship between structural changes in international trade and national economic performance seems as relevant as ever. Related to such concerns a large empirical literature ${ }^{4}$ has developed focusing on the interaction between structural changes in world demand at the one hand, and the specialisation pattern of countries on the other, with the purpose of distinguishing between the part of a country's export performance that may be attributed to structural factors and what can be explained by competitiveness within more narrowly defined market segments. The basic idea is that the total market share of a country on the world market may change over time even if the market shares of the country in each commodity group and each individual market (country) are assumed constant. This change is then referred to as caused by structural factors, i.e., to what extent the commodities and markets that the country happens to specialise in grow faster or slower than the average. Since these structural effects are calculated holding individual market shares constant, this methodology was dubbed Constant Market Share analysis (or CMS analysis).

CMS analyses are of a descriptive nature. The relevance of such analyses, and the interpretation of the various effects, depend on how the working of the global economy is conceived. First, if there is not a stable trend in the process of structural change itself, these changes (and the ability to adapt to them) lose much of their significance. Thus, the structural changes in world trade cannot be entirely random. Second, as discussed above, there has to be certain advantages accruing to countries specialising in commodities and markets for which international demand grows relatively rapidly. These may, for example, be of a Keynesian nature, allowing for a higher degree of utilisation of available resources (lower unemployment, for instance). A high growth of the demand for exports may also help

Helpman 1995). The empirical validity of the latter assertion is questioned, however (Gittleman and Wolff 1995, Verspagen 1997).

${ }^{4}$ For surveys of the literature. see Richardson 1971 and Fagerberg and Sollie 1987. 
countries deploy their resources more efficiently by pulling resources from areas with low profitability to the more profitable ones. Furthermore, there may be positive externalities attached to these high growth industries, either of an industry-specific or economywide nature, which make specialisation in these industries attractive. Third, as predicted by several theoretical contributions from the last decades, there has to be a certain element of inertia attached to existing patterns of specialisation. Clearly, in a world of global "perfect competition", CMS analysis makes little sense, because different countries then would be assumed to adapt instantaneously to changes in external and internal conditions, provided that these changes were profitable to undertake.

The next section looks at the changing commodity composition of OECD trade in the 1960s, 1970s and 1980s. We ask to what extent there is a common trend in the structural changes of these three decades and if so, what accounts for this trend. Then a CMS analysis is carried out for the OECD countries in the same periods. Special attention is paid to the impact of a country's specialisation pattern on its trade performance and how flexible the country is in adapting itself to the changing commodity composition of international demand.

Structural changes in world trade - how predictable are they?

In this section we focus on the changes in the commodity composition in world trade in three periods: 1960s, the 1970s and the 1980s. Our sample, based on OECD statistics, contains the trade between the OECD countries themselves and between the OECD and the rest of the world. Thus, intra-trade between non-OECD countries (China and India, for instance) is not included. The data base, developed at the University of Aalborg (Denmark) from OECD sources, consists of 60 commodities. A considerable effort has been made to specify 
commodities from industries with high R\&D outlays as separate commodities. A complete listing of commodities (and their SITC classifications) may be found in the Appendix.

To see to what extent there is a stable component in the changing commodity composition in international trade in the three periods covered by our investigation, we regress the growth of world trade by commodity of a period on corresponding growth for the preceding period. The results of this exercise, which was carried out both for all products and for manufacturing only, are found in Table 1. The structural changes of the 1980s were found to be strongly correlated with the corresponding figures for the 1960s and 1970s. Together the structural changes of the preceding periods explained about two-thirds of that of 1980s. However, the 1960s turned out to be a better predictor than the 1970s (although both were highly significant). Also, the structural changes in the 1960s appear to be not strongly correlated with those of the 1970s. This conclusion, it may be noted, holds even more strongly when raw materials and oil and gas are excluded (regressions 1.5 to 1.8).

However, the main finding is that structural changes in world trade are strongly correlated over the time, thus a stable component exists. What, then, is this common element in the process of structural change in the past three decades? Following a Schumpeterian prospective (see Fagerberg 2002), we should expect a close correlation between growth and R\&D intensity of the activity in question. A tentative test of this suggestion is included in Table 2. The division of commodities into high, medium and low R\&D intensity is adapted from OECD sources (see Fagerberg 1997). As the actual source operated with a higher level of aggregation (fewer commodities or sectors), we had to assume that what applied to the aggregate sector also applied to its components. Probably this does not cause much problem, because commodities from high R\&D industries appeared to be relatively well specified in both classifications. However, since we did not have actual numbers for each commodity, we 
applied a dummy variable approach, with the dummies specifying whether the commodity in question originated from a high, medium or low R\&D-intensive industry.

The results from this exercise are reported in Table 2. The first regression (2.1) shows that there is a strong correlation between high growth and high R\&D intensity in the 1980s. The result suggests that trade in products from high $R \& D$ industries grows about $4 \%$ faster than other trade, and that this difference is highly significant. This result is not much affected by the inclusion of the structural changes of the 1970s as an additional explanatory factor, which lends some credibility to the assertion of a causal relationship between R\&D intensity and superior growth. When also the structural changes of the 1960s are added, the estimated growth premium to $\mathrm{R} \& \mathrm{D}$-intensive commodities declines, but it is still positive (significant at the $5 \%$ level). However, the difference between the predictive power of this regression and one in which there is a common constant term (i.e., no dummies for differences in R\&D intensity) is not large. The reason for this is that the process of structural change of the 1960s also happens to be closely correlated with $R \& D$ intensity.

A cursory look at the data reveals more stability in the upper than the lower end of distribution. In Table 3 we look exclusively at the upper quartile of our sample (when ranked from highest to lowest growth). Eight commodities were among the fifteen most fast-growing ones in all three periods. Five more belonged to the top fifteen growers in two of three periods. If we take these thirteen commodities as indicative of stable, high-growth commodities, what is most striking is the overwhelming dominance of commodities from electronics and related industries. ${ }^{5}$ Many of these showed spectacular growth: the share of computers in OECD trade increased more than seven times between 1965 and 1990, to quote the most extreme example. Altogether, the share of electronics and related industries in

\footnotetext{
${ }^{5}$ The evidence presented here clearly fits the Schumpeterian perspective of long run economic change,i.e., a succession of qualitatively different growth regimes or
} 
OECD trade increased by a factor of three, from four to twelve per cent, during this period. However, the group of fast-growing commodities also includes furniture and clothing, which are distinctly not R\&D intensive. Thus, the apparent stability in the process of structural change in OECD trade since the 1960s cannot solely be explained by the fast growth of electronics and other R\&D intensive industries, although this clearly was an important, and perhaps decisive, factor.

This section has shown that although important differences exist between the pattern of structural change of the 1980s compared to that of previous decades, there nevertheless remains a strong common element. Perhaps the most important reason for this is that trade in commodities originating from R\&D-intensive industries, in particular electronics, tends to grow faster than other trade. This pattern is consistent with a Schumpeterian perspective on how the structure of production and trade should be expected to evolve (Dosi Pavitt and Soete 1990, Fagerberg 2002).

\section{Structural change and trade performance - a CMS analysis}

How do these structural changes impact different countries, and how do they adapt? The analysis of this issue in this paper is based on a CMS method developed by Fagerberg and Sollie (1987). As noted earlier the basic idea, common to all versions of the CMS methodology, is that the total market share of a country on the world market may change over time even if the market shares of the country are constant in each commodity group and each individual market (country). The reason for this is two-fold. First, demand may grow faster for some commodities than others. This is assumed to affect countries that are specialised in high-growth products favourably. This is the so-called commodity composition effect.

"technological revolutions". For a recent restatement of this perspective which includes an 
Similarly, demand may also grow faster in some markets (countries) than others, and this gives rise to a so-called market composition effect, favouring countries that happen to be specialised in fast-growing markets. However, the total market share of a country may also change due to changes in market shares for individual commodities in individual markets. This is the so-called market share effect which is often attributed to competitiveness. But when market shares for individual commodities or individual markets change, they are not likely to do so uniformly. This gives rise to interaction effects; the commodity adaptability effect and the market adaptability effect. These effects measure the ability of a country to change its export structure in the direction of fast-growing commodities and markets. They may thus be interpreted as measures of how flexible a country is in adapting itself to changing external conditions. In other versions of the CMS methodology interaction effects are normally ignored. Thus, the main merit of the present method (compared to others) is to focus explicitly on these effects and their economic interpretation. A formal presentation of the method is given in the Appendix.

The analysis was carried out for the twenty OECD countries covered by our investigation and "the rest of the world" $\left(\mathrm{ROW}^{6}\right)$. Oil and gas were excluded from the calculations. Since our data base also included the OECD's trade (exports and imports) with the rest of the world, we were able to include the importance of these non-OECD countries, both as a market for OECD exports and as a competitor on OECD markets. The results of the calculations can be found in tables 4-6.

We will in the following mainly focus on the structural changes in the commodity composition of world trade and how countries adapt to these changes. Figures 1-3 plot the

analysis of the role of the electronics revolution see Freeman and Louca (2000).

${ }^{6}$ The ROW comprises all non-OECD member countries and, in addition, Australia and New Zealand. The reason for the inclusion of the latter in the non-OECD aggregate is that these countries were not OECD members in the 1960s and hence not included in the OECD statistics (except as trading partners for the then OECD members). 
commodity adaptation effects against the commodity composition effect for the three different time periods covered by our investigation. The countries that are positively affected by the changing commodity composition of world demand, i.e., those that happen to be specialised in high-growth industries, are to the right, the others to the left. The distribution tends to be relatively stable through time. The countries that are positively affected contain all the large and medium-sized high-income countries of our sample; the USA, Japan, France, Italy, Germany and the UK, and some small ones. In the 1960s, there were five small countries in this group; Austria, Belgium, Netherlands, Sweden and Switzerland, but in the 1980s only the two latter remained. The remaining countries of our sample, i.e., those that were specialised in low-growth industries throughout the period, include all the low-income countries; Turkey, Greece, Ireland, Spain and Portugal, but also Canada and three Nordic countries.

The most fortunate countries are those that both gain from the changing commodity composition of world demand and adapt well to these changes. These are located too the upper right in figures 1-3. With the exception of the USA and, in particular, Japan this tends to be an empty set. In fact, most countries with positive commodity composition effects do no adapt well (lower right). This holds for all the large, high-income European countries but also for Sweden and Switzerland.

The majority of the countries that show good adaptability belong to the ones that were negatively affected by the changing commodity structure of demand (upper left); six in the 1960 s, five in the 1970 s and only two in the 1980 s. $^{7}$ There is not much stability, though. Only Portugal belongs to this group in all three periods.

\footnotetext{
${ }^{7}$ The fact that only four of twenty countries turn up with positive commodity adaptation effects in the 1980s may be a bit worrying. A priori one would have expected a more equal distribution. However, the size of a country's exports and imports also matters, e.g., one large country may outweigh many small ones. In this case the two by far largest countries of our sample (the USA and Japan) both have positive commodity adaptation effects. In addition,
} 
The same lack of stability applies to the countries that were in the least fortunate position, i.e., the ones for which both the commodity composition and adaptability effects contributed negatively (lower left). To some extent this is the result of the deviating trends of the 1970s: of the four countries that belonged to this group in the 1960s, three reappeared in the same group in the 1980s (Greece, Norway and Spain). However, in the 1980s they were joined by a number of other small countries as well (all high income). Thus, small, highincome countries are increasingly at odds with the structural changes in world trade

An interesting aspect of the results (tables 4-6) is the increasing importance of specialisation in electronics, broadly defined. ${ }^{8}$ In the 1960 s there were only one country, Japan, for which specialisation in electronics mattered a lot for its export performance. In that case, electronics accounted for most of the structural effects, which were positive, and about one-third of the total increase in market share. However, over the years electronics came to play an increasingly important role in world trade. In the 1980s, the positive commodity composition effects that the large and medium-sized, rich countries of the OECD area enjoyed, were almost entirely explained by these countries' specialisation in electronics. However, with the exception of Japan, these countries lost market shares for individual electronic products in individual markets and generally did not adapt well to the changing structure of world demand.

Among the small, rich countries of the OECD area, some countries (Sweden, Switzerland) showed similar structural features as the larger ones. As their larger European neighbours, these countries lost market shares in electronics during the 1980s, and generally did not adapt well. There are, however, some small countries with a better performance in

there is another "large country" (the rest of the world, ROW) that also shows good adaptability in this period.

${ }^{8}$ Electronics as defined here contains computers, semiconductors, telecommunication equipment, machinery and equipment for production and distribution of electricity, consumer electronics and instruments. 
electronics. Finland and Austria may be mentioned. Although these countries generally experienced negative structural effects, they gained market shares in electronics during the 1980s and this contributed positively to the adaptability effects. This experience was also shared by some of the poorer OECD member countries, in particular Ireland, and to a lesser extent Portugal, Spain and Turkey. Interestingly, the same pattern applies for the non-OECD countries as a group (ROW, see Table 7).

The ROW lost market shares to the OECD countries both in the 1960s and 1970s. One important reason behind this appears to be that they were specialised in low-growth commodities (a negative commodity composition effect). However, during the 1970s this started to change. The ROW started to gain market shares in high-growth areas such as electronics and traditional manufacturing products (clothing and furniture), and this contributed positively to both the commodity adaptation effect and the total market share. During the 1980s the gain in market share in clothing lost momentum but accelerated in electronics. Together with a strong positive market composition effect the resulting gain in adaptability was sufficient to outweigh the negative impulse from the continuing specialisation in traditional low-growth products. As a consequence the total market share of the non-OECD countries as a group increased markedly during the 1980s. This is mirrored in a similar decline for most of the high-income member countries during this period.

\section{Concluding remarks}

We may sum up our findings as follows:

1. The change in the commodity composition of world demand in recent decades has not been entirely random. As would be expected following a Schumpeterian perspective 
commodities from high R\&D industries grows much faster than other trade. This applies in particular for electronics. But also some traditional manufacturing industries that do little R\&D (clothing, furniture) grew fast during this period.

2. For the large and medium-sized, rich countries of the OECD area, commodity composition has had a positive impact. This is increasingly explained by the specialisation of these countries in electronics. However, with the exception of Japan and to a lesser some extent the USA, these countries do not adapt well to the structural changes in demand.

3. Regarding the small, rich countries, two different patterns can be observed. Some countries (Sweden, Switzerland) have similar structural characteristics as the larger ones. As their larger European neighbours, these countries experience positive commodity composition effects but do not adapt well. Others, including the remaining Nordic countries, are characterised by both negative commodity composition effects and - in the 1980s - (quite large) negative commodity adaptation effects. Thus, all small, high-income OECD countries appear to adapt badly.

4. The low-income OECD countries (Greece, Ireland, Turkey, Portugal and Spain) and the non-OECD countries as a group (ROW) were all negatively affected by the changing commodity composition of demand throughout the period. Apart from that their performance has fluctuated a lot. However, in the most recent decade all but Greece have gained market shares (a positive market share effect). Many of them have also adapted well to the changing composition of world demand.

It has been suggested (Katzenstein 1985) that the small, high-income countries of Europe compensate for the disadvantage of small size by being more receptive to changing external conditions (flexibility). There are, of course, many aspects to this, the ability to adapt the 
export structure to changes in the composition of world demand being one. However, at least in this sense, the small, high-income countries of Europe have not proven to be more flexible than other countries. This is especially evident in the most recent decade. The main factor behind this outcome appears to be the failure of these countries to carve out sustainable niches for themselves in the fast-growing electronics cluster. Increasingly, electronics tend to be dominated by the rich, large countries (the USA and Japan) on the one hand and a group of low- (or medium-) income countries on the other. The ability of such countries to increase their presence the fast growing electronics cluster is also shown to be associated with superior growth performance (Fagerberg 2000).

How do the findings of this paper conform to our theoretical priors? As noted in the introduction neo-classical theory used to downplay the importance of structural factors assuming (at least implicitly) a high degree of flexibility and adaptability of countries. However, more recent theoretical exercises, whether of the "new growth" or more "evolutionary" strand, have come to focus more on the factors leading to path-dependency and inertia in how countries develop and adapt to external challenges. Similar concerns are starting to arise in the applied literature on the economic and institutional dynamics behind these patterns (Etzkowitz and Leydesdorff 2000, Narula 2002). There is certainly a good deal of path dependency and inertia in the numbers presented here. In fact, the commodity adaptability effects are in most cases negative and rather small (compared to "commodity composition" and "market share" effects). However, some countries and country groupings do not conform to this pattern such as, in the most recent period, Ireland, Japan, Portugal and "rest of the world". 9 It is an important task for future research to dig deeper into why some

\footnotetext{
${ }^{9}$ The good performance of the latter is no doubt driven by a small number of fast growing countries, in particular the so-called "newly-industrializing countries" in Asia. Following the publication of the World Bank's "Miracle" report (World Bank 1993) a heated debate occured on the the extent to which this superior peroformance was related to policy
} 
countries manage to exploit the opportunities offered by the structural changes in world production and trade much better than others.

interventions in these countries or - on the contrary - the lack of such. See Cappelen and Fagerberg (1995) for an account of this debate. 


\section{References}

Beckerman, W. (1962) Projecting Europe's Growth, Economic Journal 72: 912-925

Cappelen, A. and J. Fagerberg (1995) East Asian Growth: A Critical Assessment, Forum for Development Studies, No. 2, pp. 175-195, reprinted in Fagerberg,J. (2002) Technology, Growth and Competitiveness: Selected Essays, Cheltenham: Edward Elgar, pp. 30-50

Coe, D.T. and E. Helpman (1995) International R\&D Spillovers, European Economic Review 39: 859-887

Dosi, G., K. Pavitt, and L.G. Soete (1990) The Economics of Technical Change and International Trade, London: Harvester Wheatsheaf

Dowrick, S. (1997) Trade and Growth: A Survey, in J. Fagerberg, P. Hansson, L. Lundberg and A. Melchior (eds.) Technology and International Trade, Aldershot: Elgar, pp. 107-126

Etzkowitz, H. and L. Leydesdorff (2000) The dynamics of innovation: from National Systems and "Mode 2" to a Triple Helix of university-industry-government relations, Research Policy 29: 109-123

Fagerberg, J. and G. Sollie (1987) The Method of Constant-Market-Shares Analysis Reconsidered, Applied Economics 19: 1571-1583

Fagerberg, J. (1997) Competitiveness, Scale and R\&D, in J. Fagerberg, P. Hansson, L. Lundberg and A. Melchior (eds.) Technology and International Trade, Aldershot: Elgar, pp. 38-54

Fagerberg, J. 2000. Technological Progress, Structural Change and Productivity Growth: a Comparative Study, Structural Change and Economic Dynamics, 11: 393-411.

Fagerberg,J. (2002) Technology, Growth and Competitiveness: Selected Essays, Cheltenham: Edward Elgar

Freeman, C. and F. Louca (2001) As Times Goes By. From the Industrial Revolutions to the Information Revolution, Oxford: Oxford University Press

Gittleman, M. and E. N. Wolff (1995) R\&D Activity and Cross-Country Growth Comparisons, Cambridge Journal of Economics 19: 189-207

Jaffe, A. B., M. Trajtenberg and R. Henderson (1993) Geographic Localization of Knowledge Spillovers as Evidenced by Patent Citations, Quarterly Journal of Economics 108: $557-598$

Grossman, G.M. and E. Helpman (1991) Innovation and Growth in the Global Economy, Cambridge (USA): The MIT Press

Kaldor, N. (1970) The Case for Regional Policies, Scottish Journal of Political Economy 17: $337-348$

Kaldor, N. (1981) The Role of Increasing Returns, Technical Progress and Cumulative Causation in the Theory of International Trade and Economic Growth, Economie Appliquée (ISMEA) 34: 593-617

Katzenstein, P. (1985) Small States in World Markets, Itacha: Cornell University Press 
Lucas, R. E. (1988) On the Mechanisms of Economic Development, Journal of Monetary Economics 22: 3-42

Maurseth, P. and B. Verspagen (1999). “Europe: One or Several Systems of Innovation?" in Fagerberg, J., P. Guerrieri and B. Verspagen (eds.) (1999). The Economic Challenge for Europe: Adapting to Innovation-based Growth. Aldershot: Edward Elgar , pp. 149-174

Narula, R. (2002) Innovation systems and 'inertia' in R\&D location: Norwegian firms and the role of systemic lock-in, Research Policy 31: 795-816

Richardson, J.D. (1971) Constant-Market-Shares Analysis of Export-Growth, Journal of International Economics 1: 227-239

Robson, P. (1987) The Economics of International Integration, 3rd Ed., London: Allen \& Unwin

Thirlwall, A.P. (1979) The Balance of Payments Constraint as an Explanation of International Growth Rate Differences, Banca Nazionale del Lavoro Quarterly Review 32: $45-53$

Verspagen, B. (1997) Estimating International Technology Spillovers Using Technology Flow Matrices, Weltwirtschaftliches Archiv 133: 226- 248

World Bank (1993) The East Asian Miracle. Economic Growth and Public Policy, New York: Oxford University Press 
ALL PRODUCTS

\begin{tabular}{|c|c|c|c|c|}
\hline & $\mathrm{G}_{69-79}$ & $\begin{aligned}= & 0.94 \\
& (2.22)\end{aligned}$ & + & $\begin{array}{l}0.18 \mathrm{G}_{65-69} \\
(2.52)\end{array}$ \\
\hline
\end{tabular}

$$
\begin{array}{rlrl}
\mathrm{R}^{2} & = & 0.10 & (0.08) \\
\mathrm{SER} & = & 3.27 \\
\mathrm{~N} & = & 60
\end{array}
$$

$\begin{aligned} & 1.2 \quad \mathrm{G}_{79-90}= 0.31 \\ &(1.06)\end{aligned}+\begin{aligned} & 0.44 \mathrm{G}_{65-69} \\ & (8.69)\end{aligned}$

$$
\begin{aligned}
\mathrm{R}^{2} & =0.57(0.56) \\
\mathrm{SER} & =2.27 \\
\mathrm{~N} & =60
\end{aligned}
$$

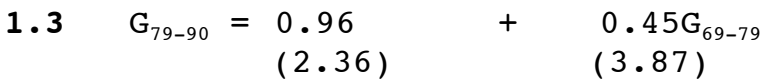

$\begin{array}{rlrl}\mathrm{R}^{2} & = & 0.21 & (0.19) \\ \mathrm{SER} & = & 3.07 \\ \mathrm{~N} & =60\end{array}$

1.4

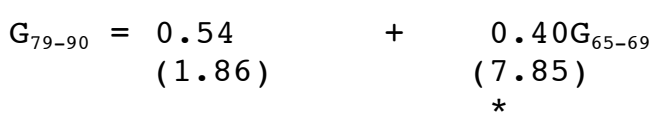

$0.24 \mathrm{G}_{69-79}$ $(2.80)$

$$
\begin{array}{rlrl}
\mathrm{R}^{2} & = & 0.62(0.60) \\
\mathrm{SER} & = & 2.15 \\
\mathrm{~N} & =60
\end{array}
$$

\section{MANUFACTURING}

$$
\begin{aligned}
& 1.5 \quad \mathrm{G}_{69-79}=-\underset{(0.64)}{0.22}+\underset{(0.10)}{0.09 \mathrm{G}_{65-69}} \\
& \mathrm{R}^{2}=0.02(-0.01) \\
& \mathrm{SER}=3.32 \\
& \mathrm{~N}=37
\end{aligned}
$$

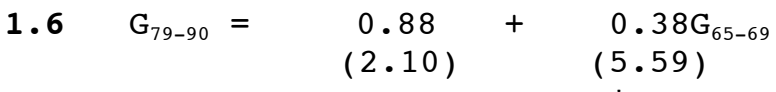

$$
\begin{aligned}
& \begin{array}{rll}
\mathrm{R}^{2} & = & 0.47(0.46) \\
\mathrm{SER} & = & 2.17 \\
\mathrm{~N} & =37
\end{array} \\
& \begin{array}{cc}
1.7 \quad \mathrm{G}_{79-90}=\underset{(5.06)}{2.08} \\
*
\end{array}+\begin{array}{c}
0.49 \mathrm{G}_{69-79} \\
(3.86)
\end{array} \\
& \begin{aligned}
\mathrm{R}^{2} & =0.30(0.28) \\
\mathrm{SER} & =2.50 \\
\mathrm{~N} & =37
\end{aligned} \\
& \begin{array}{cc}
1.8 \quad \mathrm{G}_{79-90}=\begin{array}{c}
0.97 \\
(2.91) \\
*
\end{array} & \begin{array}{c}
0.34 \mathrm{G}_{65-69} \\
(6.30) \\
*
\end{array}
\end{array} \\
& 0.41 \mathrm{G}_{69-79} \\
& (4.64) \\
& \begin{array}{rlrl}
\mathrm{R}^{2} & = & 0.68(0.66) \\
\mathrm{SER} & = & 1.72 \\
\mathrm{~N} & =37
\end{array}
\end{aligned}
$$


$\underline{\text { Notes }}$

$\mathrm{G}=$ annual growth in world trade by product, less total growth in world trade, current prices.

Absolute t-statistics in brackets, one and two stars denote significance, $1 \%$ and 5\% level.

$\mathrm{R}^{2}$ in brackets is adjusted for degree of freedom.

$\mathrm{SER}=$ standard error of regression (root MSE).

$\mathrm{N}=$ number of product groups included in the text. 


\section{ALL PRODUCTS}

\begin{tabular}{|c|c|c|c|c|c|c|c|}
\hline 3.1 & $\mathrm{G}_{79-80}=$ & $\begin{array}{c}-1.04 \text { LOW } \\
(2.05) \\
\star \star\end{array}$ & + & $\begin{array}{l}0.79 \text { MED } \\
(1.21)\end{array}$ & + & $\begin{array}{l}4.35 \text { HIGH } \\
(5.44) \\
*\end{array}$ & $\begin{array}{l}R^{2}=0.36 \quad(0.33) \\
S E R=2.77 \\
N=60\end{array}$ \\
\hline 3.2 & $\mathrm{G}_{79-80}=$ & $\begin{array}{c}-0.57 \text { LOW } \\
(1.14)\end{array}$ & + & $\begin{array}{l}1.06 \text { MED } \\
(1.72)\end{array}$ & + & $\begin{array}{l}4.06 \text { HIGH } \\
(5.39) \\
*\end{array}$ & \\
\hline & & $\begin{array}{l}+0.31 \mathrm{G}_{69-79} \\
(3.05)\end{array}$ & & & & & $\begin{array}{l}R^{2}=0.45 \quad(0.42) \\
S E R=2.59 \\
N=60\end{array}$ \\
\hline 3.3 & $\mathrm{G}_{79-80}=$ & $\begin{array}{c}-0.03 \text { LOW } \\
(0.08)\end{array}$ & + & $\begin{array}{l}0.82 \text { MED } \\
(1.63)\end{array}$ & + & $\begin{array}{l}1.68 \text { HIGH } \\
(2.22) \\
* \star\end{array}$ & \\
\hline & & $\begin{array}{c}+0.33 \mathrm{G}_{65-69} \\
(5.39) \\
*\end{array}$ & + & $\begin{array}{l}0.22 \mathrm{G}_{69-79} \\
(2.63) \\
\star *\end{array}$ & & & $\begin{array}{l}R^{2}=0.64 \quad(0.61) \\
S E R=2.12 \\
N=60\end{array}$ \\
\hline
\end{tabular}

Notes

LOW, MED, HIGH = LOW, medium and high R\&D intensity defined as follows (see appendix) :

HIGH: Products $27,39-42,44,46-49,52$ and 59

MEDIUM: $24-26,28,31-38,43,45,50,51,54$ and 55

LOW: $1-23,29,30,53,56-58,60$

Other variables and definitions, see Table 1. 
A) Fast-growing in the entire period:

$\begin{array}{cr}\text { Share of world trade (\%) } \\ 1965 & 1990 \\ 0.5 & 3.6 \\ 0.3 & 1.8 \\ 0.5 & 1.4 \\ 0.3 & 1.0 \\ 1.6 & 3.5\end{array}$

B) Fast-growing in the entire period less the 1960s:

Telecommunication eq. (42)

$0.8 \quad 1.6$

Machinery for production \& distribution of electricity (43)

1.5

2.4

C) Fast-growing in the entire period less the 1970s

Consumer electronics (44)

0.6

1.4

Aircraft (52)

0.9

1.7

D) Fast-growing in the entire period less the 1980s:

Plastics (29)

0.9

2.1

E) Fast-growing in one period only: 1980s

1970 s

1960s

Pharmaceuticals (27)

Fish etc. (3)

Aluminium (18)

Paper \& pulp machinery (33) Oil and gas (23)

Power generating machinery (37)

Industrial products, Organic chemicals (24)

Office machinery n.e.s., (60)

\section{Other chemicals (30)} (non-electronic)

Note: Numbers in brackets refer to product list in Appendix 
TABLE 4 EXPORT PERFORMANCE OF 20 OECD COUNTRIES, 1965-69

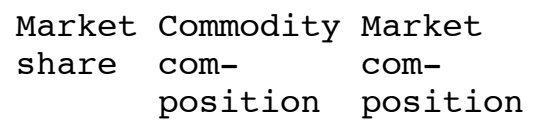

Commodity Market Total adapt- adaptation ation

\begin{tabular}{|c|c|c|c|c|c|c|}
\hline Belgium & 1.68 & 3.07 & 0.15 & 0.69 & 0.55 & 6.14 \\
\hline Electronics & -0.41 & -0.10 & -0.03 & 0.24 & -0.03 & -0.33 \\
\hline Traditional & -0.30 & 1.10 & 0.00 & -0.04 & 0.05 & 0.82 \\
\hline Canada & 2.09 & -7.71 & 5.70 & 11.02 & 3.11 & 14.20 \\
\hline Electronics & -0.21 & 0.77 & 0.12 & 0.08 & 0.08 & 0.84 \\
\hline Traditional & 0.30 & 0.16 & 0.02 & 0.19 & 0.11 & 0.78 \\
\hline Denmark & -2.81 & -6.24 & -6.43 & 0.71 & 0.14 & -14.62 \\
\hline Electronics & 0.04 & 0.74 & -0.24 & -0.14 & -0.10 & 0.30 \\
\hline Traditional & -0.29 & 1.57 & -0.18 & -0.17 & -0.17 & 0.74 \\
\hline UK & $-14 \cdot 94$ & 6.99 & -1.76 & -3.88 & 0.07 & $-13 \cdot 52$ \\
\hline Electronics & -1.52 & 1.24 & -0.17 & -0.45 & 0.06 & -0.85 \\
\hline Traditional & -0.10 & 0.44 & -0.00 & -0.02 & -0.05 & 0.27 \\
\hline Finland & 4.62 & -4.68 & $-5 \cdot 58$ & 0.80 & -1.11 & -5.95 \\
\hline Electronics & 0.24 & 0.09 & -0.10 & 0.09 & -0.04 & 0.28 \\
\hline Traditional & 1.81 & 0.21 & -0.06 & 0.69 & -0.26 & 2.37 \\
\hline France & 3.04 & 1.64 & -2.40 & -1.86 & 0.07 & 0.49 \\
\hline Electronics & 0.02 & 0.72 & -0.17 & 0.08 & -0.03 & 0.62 \\
\hline Traditional & -0.47 & 0.53 & -0.08 & -0.04 & 0.04 & -0.02 \\
\hline Greece & 24.27 & -8.05 & -1.66 & -2.42 & 0.00 & 12.14 \\
\hline Electronics & 0.48 & 0.06 & -0.02 & -0.11 & 0.01 & 0.42 \\
\hline Traditional & 1.44 & 0.31 & -0.03 & 0.35 & -0.07 & 2.00 \\
\hline Netherlands & 6.50 & 0.36 & -1.55 & -1.50 & 0.00 & 3.82 \\
\hline Electronics & -1.62 & 1.67 & 0.03 & -0.41 & -0.05 & -0.38 \\
\hline Traditional & -0.28 & 0.74 & -0.01 & -0.14 & 0.02 & 0.32 \\
\hline Ireland & 18.88 & -5.60 & -10.90 & -1.18 & -1.22 & -0.02 \\
\hline Electronics & -0.08 & 1.45 & 0.06 & -0.29 & 0.02 & 1.16 \\
\hline Traditional & 0.59 & 1.24 & -0.32 & 0.28 & -0.36 & 1.43 \\
\hline Switzerland & -0.33 & 10.92 & -0.95 & -2.14 & -1.45 & 6.05 \\
\hline Electronics & -0.23 & 1.36 & -0.16 & -0.09 & -0.10 & 0.78 \\
\hline Traditional & -0.54 & 0.67 & -0.04 & -0.15 & -0.06 & -0.11 \\
\hline Turkey & -3.76 & -18.09 & -0.31 & 0.55 & -0.48 & -22.08 \\
\hline Electronics & -0.02 & 0.02 & -0.01 & -0.01 & 0.00 & -0.02 \\
\hline Traditional & 0.08 & 0.01 & 0.00 & 0.01 & -0.00 & 0.10 \\
\hline Italy & 6.66 & 6.89 & -1.58 & -0.59 & 0.27 & 11.65 \\
\hline Electronics & 0.64 & 1.15 & -0.07 & 0.05 & -0.05 & 1.72 \\
\hline Traditional & -0.19 & 2.34 & 0.16 & -0.12 & 0.05 & 2.23 \\
\hline
\end{tabular}




$\begin{array}{lrrrrrr}\text { Japan } & 18.99 & 6.88 & 0.21 & -0.90 & -0.30 & 24.88 \\ \text { Electronics } & 2.46 & 5.07 & 0.38 & 0.41 & 0.36 & 8.67 \\ \text { Traditional } & -0.54 & 0.46 & 0.18 & -0.09 & 0.04 & 0.04 \\ & & & & & & \\ \text { Norway } & 7.21 & -1.43 & -5.53 & -0.85 & -1.68 & -2.29 \\ \text { Electronics } & -0.14 & 0.57 & -0.13 & -0.13 & -0.06 & 0.11 \\ \text { Traditional } & -0.39 & 0.59 & -0.06 & -0.21 & -0.02 & -0.08 \\ & & & & & & \\ \text { Austria } & 4.36 & 3.20 & -2.15 & 0.02 & -1.38 & 4.06 \\ \text { Electronics } & 0.18 & 0.92 & -0.30 & 0.38 & -0.10 & 1.09 \\ \text { Traditional } & -0.65 & 1.29 & -0.08 & -0.17 & -0.14 & 0.25 \\ & & & & & & \\ \text { Portugal } & 7.60 & -5.33 & -4.18 & 2.47 & -2.00 & -1.45 \\ \text { Electronics } & 2.37 & 0.05 & -0.07 & 0.90 & -0.07 & 3.18 \\ \text { Traditional } & 2.03 & 0.98 & -0.19 & 1.27 & -0.68 & 3.42 \\ & & & & & & \\ \text { Spain } & 30.63 & -8.71 & -1.61 & -2.22 & -0.70 & 17.40 \\ \text { Electronics } & 1.14 & 0.16 & -0.04 & 0.13 & -0.05 & 1.34 \\ \text { Traditional } & 0.63 & 0.63 & 0.09 & 0.01 & 0.00 & 1.36 \\ & & & & & & \\ \text { Sweden } & -0.01 & 2.21 & -5.31 & -1.27 & -0.84 & -5.22 \\ \text { Electronics } & 0.07 & 1.39 & -0.25 & -0.15 & -0.06 & 0.99 \\ \text { Traditional } & -0.04 & 0.69 & -0.11 & -0.00 & -0.08 & 0.45 \\ \text { Germany } & & & & & & \\ \text { Electronics } & -0.03 & 1.41 & -0.16 & -0.33 & 0.02 & 0.92 \\ \text { Traditional } & 0.03 & 0.69 & -0.00 & -0.04 & 0.01 & 0.69 \\ \text { USA } & & & & & & \\ \text { Electronics } & -0.04 & 1.43 & 0.02 & 0.11 & -0.03 & 1.49 \\ \text { Traditional } & -0.04 & 0.07 & -0.02 & -0.03 & -0.01 & -0.03\end{array}$

Note

The first row for each country is the result from the CMS analysis. The second and third rows are the contributions from electronics and traditional manufacturing, as defined here, to the various effects. Electronics contains commodity groups 40-44,46-48 and 59, traditional manufacturing groups 58 and 59 (see Appendix). 


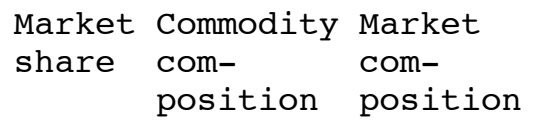

$\begin{array}{ll}\text { Commodity } & \text { Market Total } \\ \text { adapt- } & \text { adapt- }\end{array}$

ation ation

\begin{tabular}{|c|c|c|c|c|c|c|}
\hline Belgium & -5.62 & 3.77 & 2.39 & -2.21 & -0.06 & -1.73 \\
\hline Electronics & 0.02 & 0.97 & 0.14 & 0.29 & -0.02 & 1.41 \\
\hline Traditional & -1.84 & 1.33 & 0.09 & -0.55 & -0.03 & -1.00 \\
\hline Canada & -18.35 & -4.78 & -8.49 & -1.51 & 2.88 & -30.26 \\
\hline Electronics & -0.87 & 1.43 & -0.17 & -0.55 & 0.00 & -0.16 \\
\hline Traditional & -0.44 & 0.28 & -0.11 & -0.10 & 0.03 & -0.35 \\
\hline Denmark & 3.24 & -3.26 & -4.39 & -5.97 & 1.07 & $-9 \cdot 30$ \\
\hline Electronics & -0.82 & 2.19 & -0.17 & -0.56 & 0.03 & 0.67 \\
\hline Traditional & -1.80 & 2.89 & -0.60 & $-1 \cdot 31$ & 0.11 & -0.71 \\
\hline UK & -21.38 & 2.73 & 3.89 & -0.84 & -0.99 & -16.59 \\
\hline Electronics & -1.42 & 2.47 & 0.30 & -0.49 & 0.09 & 0.94 \\
\hline Traditional & -0.26 & 0.77 & 0.00 & -0.30 & 0.06 & 0.27 \\
\hline Finland & 17.50 & $-10 \cdot 32$ & -1.65 & 0.09 & -2.52 & 3.10 \\
\hline Electronics & 1.36 & 0.51 & -0.02 & 0.52 & -0.14 & 2.23 \\
\hline Traditional & 2.19 & 1.12 & -0.28 & 0.34 & -0.61 & 2.75 \\
\hline France & 13.44 & 5.47 & 5.04 & -1.64 & -0.45 & 21.86 \\
\hline Electronics & 0.57 & 2.54 & 0.34 & 0.16 & 0.10 & 3.70 \\
\hline Traditional & -0.36 & 1.04 & 0.14 & -0.27 & -0.03 & 0.51 \\
\hline Greece & 27.44 & -7.83 & 4.89 & 7.43 & 2.50 & 34.43 \\
\hline Electronics & 1.03 & 0.39 & 0.02 & 0.22 & 0.26 & 1.91 \\
\hline Traditional & 14.46 & 1.23 & 0.15 & 7.34 & 1.03 & 24.21 \\
\hline Netherlands & 1.84 & 4.14 & 3.00 & -4.50 & -0.51 & 3.97 \\
\hline Electronics & -1.78 & 3.03 & -0.03 & -1.18 & 0.22 & 0.25 \\
\hline Traditional & -0.92 & 1.28 & 0.11 & -0.67 & -0.02 & -0.22 \\
\hline Ireland & 61.09 & -7.61 & -9.70 & -9.19 & 1.17 & 35.76 \\
\hline Electronics & 3.56 & 4.84 & -0.37 & 2.24 & -0.35 & 9.91 \\
\hline Traditional & -1.46 & 3.39 & -0.50 & -1.24 & -0.03 & 0.15 \\
\hline Switzerland & 3.49 & 7.17 & 2.65 & -6.59 & 0.98 & 7.70 \\
\hline Electronics & -0.19 & 2.70 & 0.18 & -0.28 & 0.19 & 2.59 \\
\hline Traditional & -0.72 & 0.89 & -0.00 & -0.36 & 0.07 & -0.11 \\
\hline Turkey & -7.47 & -19.16 & 3.58 & 4.41 & 0.03 & -18.61 \\
\hline Electronics & 0.06 & 0.02 & -0.00 & 0.03 & 0.01 & 0.12 \\
\hline Traditional & 2.18 & 0.04 & -0.00 & 0.86 & 0.16 & 3.24 \\
\hline Italy & 4.91 & 11.02 & 4.52 & -5.29 & -0.22 & 14.94 \\
\hline Electronics & -1.86 & 3.32 & 0.30 & -1.61 & -0.03 & 0.12 \\
\hline Traditional & -0.89 & 3.38 & 0.16 & -0.09 & 0.25 & 2.80 \\
\hline
\end{tabular}




\begin{tabular}{|c|c|c|c|c|c|c|}
\hline Japan & 17.75 & 1.01 & 4.83 & 6.41 & -0.32 & 29.68 \\
\hline Electronics & 1.71 & 3.20 & -0.18 & 1.82 & 0.60 & 7.15 \\
\hline Traditional & -2.56 & 0.26 & -0.11 & -0.20 & 0.10 & -2.52 \\
\hline Norway & -10.02 & -11.20 & $-4 \cdot 30$ & 1.97 & 0.60 & -22.95 \\
\hline Electronics & 0.17 & 0.81 & -0.22 & -0.15 & 0.10 & 0.71 \\
\hline Traditional & -0.38 & 0.74 & -0.14 & -0.33 & -0.03 & -0.14 \\
\hline Austria & 18.32 & 4.49 & 2.63 & -4.35 & 1.99 & 23.07 \\
\hline Electronics & -0.15 & 2.58 & -0.06 & -0.01 & 0.30 & 2.66 \\
\hline Traditional & -0.59 & 1.76 & -0.13 & -0.26 & 0.10 & 0.87 \\
\hline Portugal & -20.84 & -3.40 & 0.27 & 4.01 & -2.10 & -22.05 \\
\hline Electronics & -0.93 & 3.18 & 0.00 & -1.53 & 0.06 & 0.78 \\
\hline Traditional & 0.85 & 2.51 & -0.65 & 0.83 & -0.26 & 3.28 \\
\hline Spain & 64.65 & -4.47 & 1.99 & 4.53 & 3.97 & 70.67 \\
\hline Electronics & 1.88 & 0.75 & 0.15 & 0.59 & 0.18 & 3.54 \\
\hline Traditional & 0.95 & 0.88 & -0.03 & 0.07 & 0.14 & 2.00 \\
\hline Sweden & -10.06 & 1.79 & -2.45 & -1.63 & -0.24 & -12.59 \\
\hline Electronics & -1.69 & 3.29 & 0.12 & -0.99 & -0.03 & 0.70 \\
\hline Traditional & -0.61 & 1.01 & -0.24 & -0.16 & 0.03 & 0.02 \\
\hline Germany & 3.30 & 7.42 & 2.28 & -3.34 & -0.31 & 9.35 \\
\hline Electronics & -0.79 & 2.62 & 0.14 & -0.42 & 0.04 & 1.59 \\
\hline Traditional & -0.15 & 0.79 & 0.06 & -0.03 & 0.02 & 0.69 \\
\hline USA & -7.83 & 2.36 & -1.87 & -0.65 & -0.07 & -8.06 \\
\hline Electronics & -0.74 & 3.33 & -0.10 & -0.24 & -0.01 & 2.25 \\
\hline Traditional & -0.04 & 0.16 & 0.03 & -0.07 & -0.04 & 0.05 \\
\hline
\end{tabular}


TABLE 6 EXPORT PERFORMANCE OF 20 OECD COUNTRIES, 1979-90

$$
\begin{aligned}
& \text { Market Commodity Market Commodity Market Total } \\
& \text { share com- com- adapt- adapt- } \\
& \text { position position ation ation }
\end{aligned}
$$

\begin{tabular}{|c|c|c|c|c|c|c|}
\hline Belgium & 1.31 & -2.25 & -0.48 & -2.91 & -0.13 & -4.47 \\
\hline Electronics & $;-1.29$ & 2.14 & -0.12 & -0.56 & 0.08 & 0.25 \\
\hline Traditional & -0.44 & 0.37 & -0.07 & -0.13 & 0.02 & -0.26 \\
\hline Canada & -0.63 & -12.40 & 14.10 & -3.03 & -2.69 & -4.65 \\
\hline Electronics & -0.19 & 4.02 & 0.40 & -1.13 & 0.44 & 3.54 \\
\hline Traditional & -0.26 & 0.49 & 0.18 & -0.11 & 0.05 & 0.36 \\
\hline Denmark & 8.66 & -5.39 & -0.31 & -2.22 & -0.69 & 0.05 \\
\hline Electronics & -0.77 & 2.81 & -0.12 & -0.43 & 0.03 & 1.52 \\
\hline Traditional & 1.12 & 1.00 & -0.06 & 0.16 & 0.08 & 2.31 \\
\hline UK & -13.08 & 6.00 & -3.88 & -1.67 & 1.50 & -11.13 \\
\hline Electronics & $;-1.09$ & 5.94 & -0.56 & -0.60 & 0.32 & 4.01 \\
\hline Traditional & -1.06 & 0.78 & -0.14 & -0.36 & 0.12 & -0.65 \\
\hline Finland & 4.51 & -1.46 & -4.65 & -1.11 & -1.05 & -3.76 \\
\hline Electronics & 3.47 & 0.92 & -0.36 & 1.60 & -0.54 & 5.09 \\
\hline Traditional & -3.84 & 0.60 & -0.44 & -0.19 & 0.19 & -3.68 \\
\hline France & -5.08 & 3.42 & -2.23 & -3.68 & 1.73 & -5.85 \\
\hline Electronics & $;-1.17$ & 4.53 & -0.41 & -1.49 & 0.08 & 1.54 \\
\hline Traditional & -0.45 & 0.67 & -0.07 & -0.10 & 0.04 & 0.09 \\
\hline Greece & -6.84 & -7.15 & -3.53 & -6.39 & 3.52 & -20.40 \\
\hline Electronics & -0.68 & 0.47 & -0.28 & -0.04 & 0.25 & -0.28 \\
\hline Traditional & -3.87 & 3.21 & 0.77 & -0.70 & -0.09 & -0.68 \\
\hline Netherlands & 5.30 & $-3 \cdot 34$ & -0.27 & -2.65 & 0.86 & -0.10 \\
\hline Electronics & -1.13 & 2.62 & -0.08 & 0.44 & 0.37 & 2.22 \\
\hline Traditional & -0.23 & 0.31 & -0.10 & 0.02 & 0.03 & 0.48 \\
\hline Ireland & 27.70 & -2.51 & 2.48 & 3.20 & 1.36 & 32.21 \\
\hline Electronics & ; 4.92 & 8.57 & 0.55 & 6.82 & 0.65 & 21.50 \\
\hline Traditional & -0.41 & 0.48 & 0.12 & 0.01 & 0.04 & 0.24 \\
\hline Switzerland & -6.81 & 10.35 & 0.20 & -1.79 & -1.33 & 0.62 \\
\hline Electronics & -2.60 & 4.00 & -0.23 & -1.47 & 0.14 & -0.16 \\
\hline Traditional & -0.29 & 0.36 & 0.04 & -0.09 & -0.00 & 0.02 \\
\hline Turkey & 167.81 & -20.94 & -1.32 & -15.89 & -11.86 & 117.80 \\
\hline Electronics & 5.79 & 0.10 & -0.01 & 1.61 & -0.45 & 7.05 \\
\hline Traditional & -46.90 & 0.70 & 0.05 & 8.12 & 1.70 & 57.47 \\
\hline Italy & -0.00 & 5.82 & -1.40 & -3.70 & 1.49 & 2.20 \\
\hline Electronics & -0.45 & 3.15 & -0.13 & -0.37 & 0.06 & 2.25 \\
\hline Traditional & -1.12 & 2.18 & 0.07 & 0.07 & 0.26 & 1.47 \\
\hline
\end{tabular}




$\begin{array}{lrrrrrr}\text { Japan } & 18.07 & 4.66 & -6.44 & 3.58 & -1.45 & 18.41 \\ \text { Electronics } & 3.93 & 10.52 & -0.64 & 2.65 & -0.59 & 15.87 \\ \text { Traditional } & -0.13 & 0.19 & 0.01 & -0.09 & -0.04 & -0.07 \\ & & & & & & \\ \text { Norway } & -9.53 & -5.00 & -2.51 & -1.91 & 0.97 & -17.99 \\ \text { Electronics } & -0.74 & 1.69 & -0.23 & -0.02 & 0.07 & 0.77 \\ \text { Traditional } & -0.74 & 0.37 & -0.03 & -0.18 & 0.02 & -0.56 \\ & & & & & & \\ \text { Austria } & 15.10 & -0.68 & -1.91 & -0.52 & 0.32 & 12.32 \\ \text { Electronics } & 1.50 & 2.66 & -0.05 & 0.79 & -0.13 & 4.77 \\ \text { Traditional } & -0.45 & 0.80 & 0.08 & 0.01 & 0.01 & 0.46 \\ & & & & & & \\ \text { Portugal } & 79.92 & -0.71 & 1.19 & 3.22 & 9.32 & 92.94 \\ \text { Electronics } & 2.56 & 3.87 & 0.30 & 0.10 & 0.47 & 7.29 \\ \text { Traditional } & 22.23 & 2.77 & 0.10 & 4.31 & 1.79 & 31.19 \\ & & & & & & \\ \text { Spain } & 23.21 & -3.51 & -2.77 & -2.29 & 4.26 & 18.89 \\ \text { Electronics } & 1.07 & 1.51 & -0.21 & 0.77 & 0.33 & 3.47 \\ \text { Traditional } & -0.78 & 0.79 & -0.05 & -0.10 & 0.10 & -0.04 \\ & & & & & & \\ \text { Sweden } & -13.04 & 3.86 & -1.27 & -4.39 & 0.97 & -13.86 \\ \text { Electronics } & -2.37 & 4.75 & -0.44 & -1.82 & 0.23 & 0.35 \\ \text { Traditional } & -0.82 & 0.53 & -0.04 & -0.19 & 0.06 & -0.46 \\ & & & & & & \\ \text { Germany } & -4.24 & 4.23 & -2.02 & -1.05 & 1.29 & -1.79 \\ \text { Electronics } & -1.41 & 4.37 & -0.11 & -1.14 & 0.08 & 1.79 \\ \text { Traditional } & -0.09 & 0.34 & -0.10 & 0.01 & 0.06 & 0.21 \\ \text { USA } & & & & & & \\ \text { Electronics } & -1.13 & 9.62 & -0.58 & -1.29 & -0.85 & 5.78 \\ \text { Traditional } & 0.02 & 0.35 & -0.09 & -0.01 & -0.07 & 0.21 \\ & & & & & & \end{array}$


TABLE 7 THE EXPORT PERFORMANCE OF THE NON-OECD COUNTRIES

$$
\text { 1965-69 }
$$

Total

effect

$-0.12$

Market share

Commodity composition

Market composition

Commodity adaptation

Market adaptation

Total

1969-79

Market share

Commodity composition

Market composition

Commodity adaptation

Market adaptation

Total

$-13.04$

3.30

0.82

$-0.76$

$-9.79$

2.62

$-14.83$

$-4.56$

6.95

$-0.23$

$-10.04$

$1979-90$
3.21

Market share

Commodity composition

Market composition

Commodity adaptation

Market adaptation

Total

3.21
-11.83
13.12
5.98
-0.71
9.78

11.83

5.98

9.78 of which:

Electronics Traditional

0.26

0.20

0.42

0.63

0.01

0.17

0.08

0.04

0.10

0.06

0.72

1.24

$\begin{array}{rr}2.47 & 2.55 \\ 0.93 & 1.92 \\ -0.12 & -0.32 \\ 1.04 & 0.86 \\ -0.41 & -0.27 \\ 3.91 & 4.74\end{array}$

2.24

3.90

0.87

3.31

1.00

1.01

2.37

1.18

0.16

0.63

10.69

5.99 


\section{APPENDIX}

\section{TABLE A 1 COMMODITY CLASSIFICATION (SITC, Revision 1)}

\section{Products based on natural resources}

\begin{tabular}{|c|c|c|}
\hline $\begin{array}{l}1 . \\
2 .\end{array}$ & $\begin{array}{l}\text { Meat \& meat preparations } \\
\text { Dairy products }\end{array}$ & $\begin{array}{l}00,01,091.3,411.3 \\
02\end{array}$ \\
\hline 3 . & Fish \& fish preparations & 411.1 \\
\hline 4 . & Cereals \& cereal preparations & 04 \\
\hline 5 . & Feeding-stuff for animals & 08 \\
\hline 6 . & Other food products & $05,06,07,091.4,099$ \\
\hline 7 . & Beverages \& tobacco & 11,12 \\
\hline 8 . & Animal \& vegetable oil \& fats & $22,42,43$ \\
\hline 9 & Cut flowers, bulbs \& other plants & $292.1-4,292.6-9$ \\
\hline 10 . & Seeds \& spores for planting & 292.5 \\
\hline 11. & Skins \& leather manufactures & $21,61,291$ \\
\hline 2 . & Wood \& wood manufactures & 24, \\
\hline 13 . & Pulp \& paper & 25, \\
\hline 14 . & Textile fibres & 26 \\
\hline 15 . & Textile yarn, fabrics, etc. & 65 \\
\hline 6 . & Iron ore & 281 \\
\hline 17. & Iron, steel \& ferro-alloys & 67 \\
\hline 18 . & Aluminium & 684 \\
\hline 9 . & Non-ferrous ores \& metals & $282-86,681-83,685-89$ \\
\hline & $\begin{array}{l}\text { Crude fertilizers, crude } \\
\text { minerals \& coal }\end{array}$ & 27,32 \\
\hline 21 . & $\begin{array}{l}\text { Non-metallic minerals (cement, } \\
\text { bricks, ceramics, glass, etc.) }\end{array}$ & 66 \\
\hline & Rest: rubber; electr. energy & $23,62,35$ \\
\hline
\end{tabular}

Oil and gas

23. Oil \& gas

33,34

\section{Chemicals}

24. Organic chemicals

25. Inorganic chemicals

513,514

26. Dyestuffs, colouring materials

53

27. Pharmaceuticals

54

28. Fertilizers, manufactured

29. Plastic materials

30. Other chemicals

56

$581.1,581.2$

$515,52,55,57$,

$581.3,581.9,59$ 


\section{Engineering, electronics and transport equipment}

31. Agricul. \& food proces. machinery

32. Textile \& sewing machinery

33. Paper \& pulp machinery

34. Machinery for other special industries or processes

35. Heating \& cooling equipment

36. Metalworking machinery

37. Power generating machinery

38. Pumps \& centrifuges

39. Typewriters \& office machinery

40. Computers \& peripherals

41. Semiconductors

42. Telecommunications equipment

43. Machinery for production \& distribution of electricity

44. Consumer electronics

45. Domestic electrical equipment

46. Electromedical equipment

47. Non-elec. medical equipment

48. Measuring \& control instruments

49. Photographic \& optical goods, watches

50. Railway vehicles

51. Road motor vehicles

52. Aircraft

53. Ships and boats (\& oilrigs)

54. Other non-electrical equipment

55. Other electrical equipment
$712,718.3$

$717.1,717,3$

718.1

$717.2,718.2,718.4-5$,

$719.3,719.5,719.8$

719.1

715

711

719.2

$714.1,714.9$

$714.2,714.3$

729.3

724.9

722,723

$724.1,724.2,891.1$

725

726

861.7

729.5

$861.1-6,861.8-9$,

862,864

731

732

734

735

$719.6-7,719.9,733$

$729.1-2,729.4,729.6-7$, 729.9

\section{Other industrial products}

56. Manufactures of metal

57. Furniture

58. Clothing

59. Orthopaed. eq. \& hearing aids

$69,719.4,812.1,812.3$

82

84

899.6

60. Industrial products, n.e.s.

$812.2,812.4,83,85$, $863,891.2-9,892-97$, 899-92, 899.1-5, 899.9, 9 


\section{CONSTANT MARKET SHARES ANALYSIS}

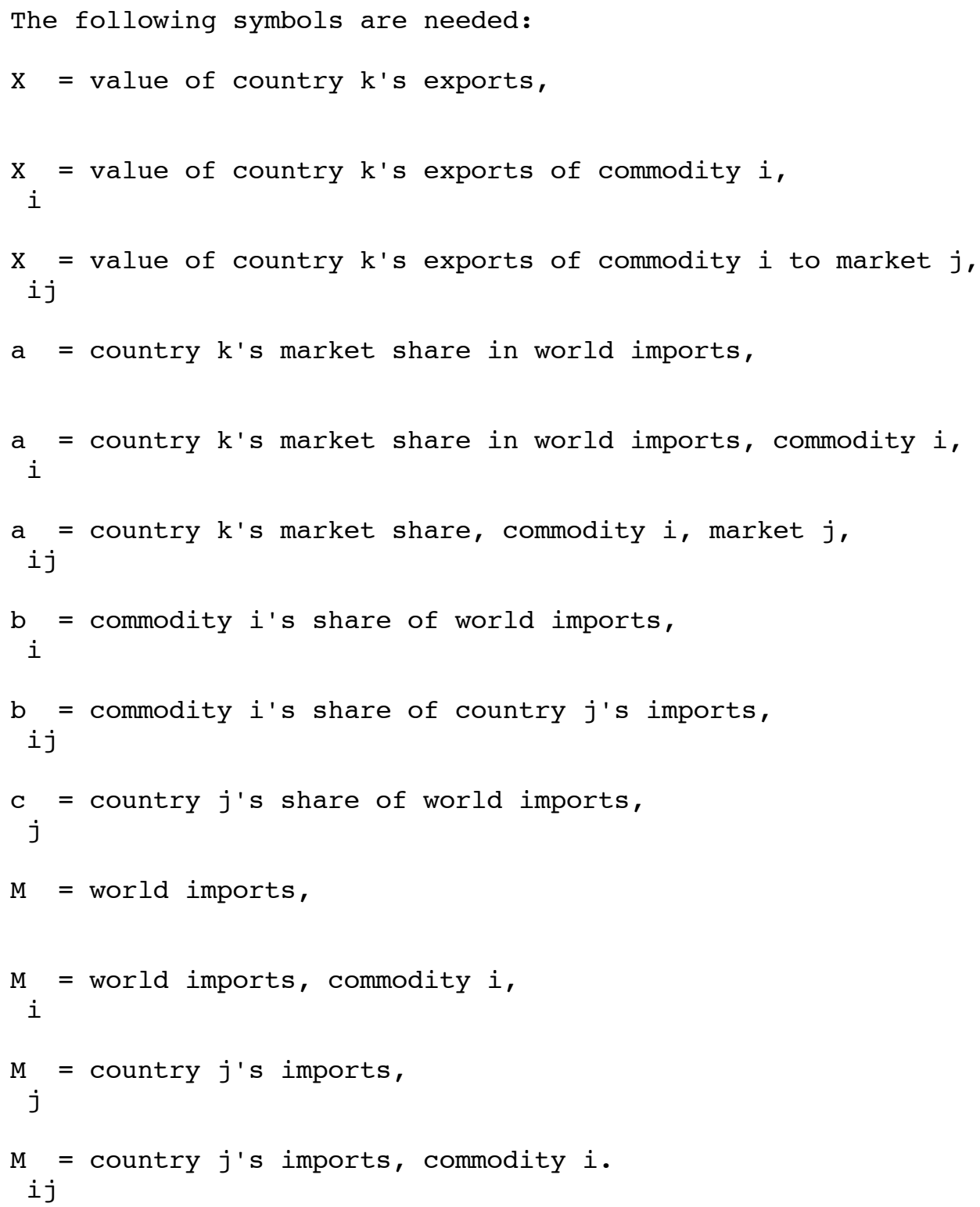

The following is true by definition:

$$
\begin{aligned}
& \mathrm{a}=\mathrm{x} / \mathrm{M}, \mathrm{a}=\mathrm{x} / \mathrm{M}, \mathrm{a}=\mathrm{x} / \mathrm{M}, \mathrm{b}=\mathrm{M} / \mathrm{M}, \mathrm{b}=\mathrm{M} / \mathrm{M} \text {, } \\
& \mathrm{C}=\mathrm{M} / \mathrm{M} \text {. } \\
& \text { j } \quad j
\end{aligned}
$$




$$
\begin{aligned}
& a=\Sigma \Sigma\left[a_{i j} b_{i j} c_{j}\right] \\
& \text { j i } \\
& d a=\Sigma \sum\left[d\left(a_{i j} b_{i j}\right) c_{j}+a_{i j} b_{i j} d c_{j}+d\left(a_{i j} b_{i j}\right) d c_{j}\right] \\
& \text { j i } \\
& d a=\sum \sum\left[d a_{i j} b_{i j} c_{j}+a_{i j} d b_{i j} c_{j}+d a_{i j} d b_{i j} c_{j}+a_{i j} b_{i j} d c_{j}+\right. \\
& j i \text { I II III II } \\
& \left.d\left(a_{i j} b_{i j}\right) d c_{j}\right]
\end{aligned}
$$

Where

$$
\begin{aligned}
& I=\text { the market share effect } \\
& I I=\text { the commodity composition effect } \\
& \text { III }=\text { the commodity adaptation effect } \\
& \text { IV }=\text { the market composition effect } \\
& V=\text { the market adaptation effect }
\end{aligned}
$$

For proofs and details, see Fagerberg and Sollie (1987) 


\section{Structure and Adaptability}

20 OECD Countries 1965-69

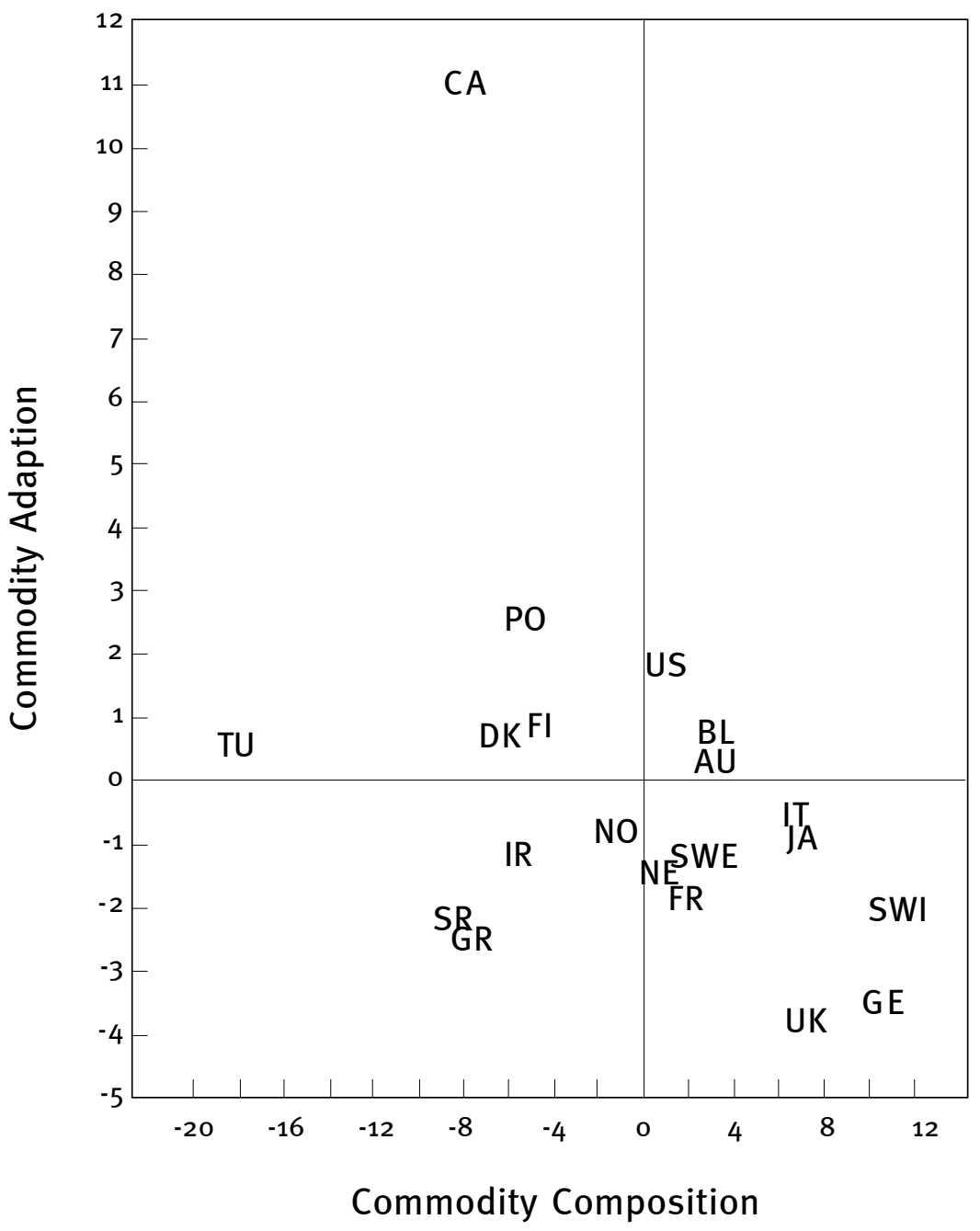


Structure and Adaptability

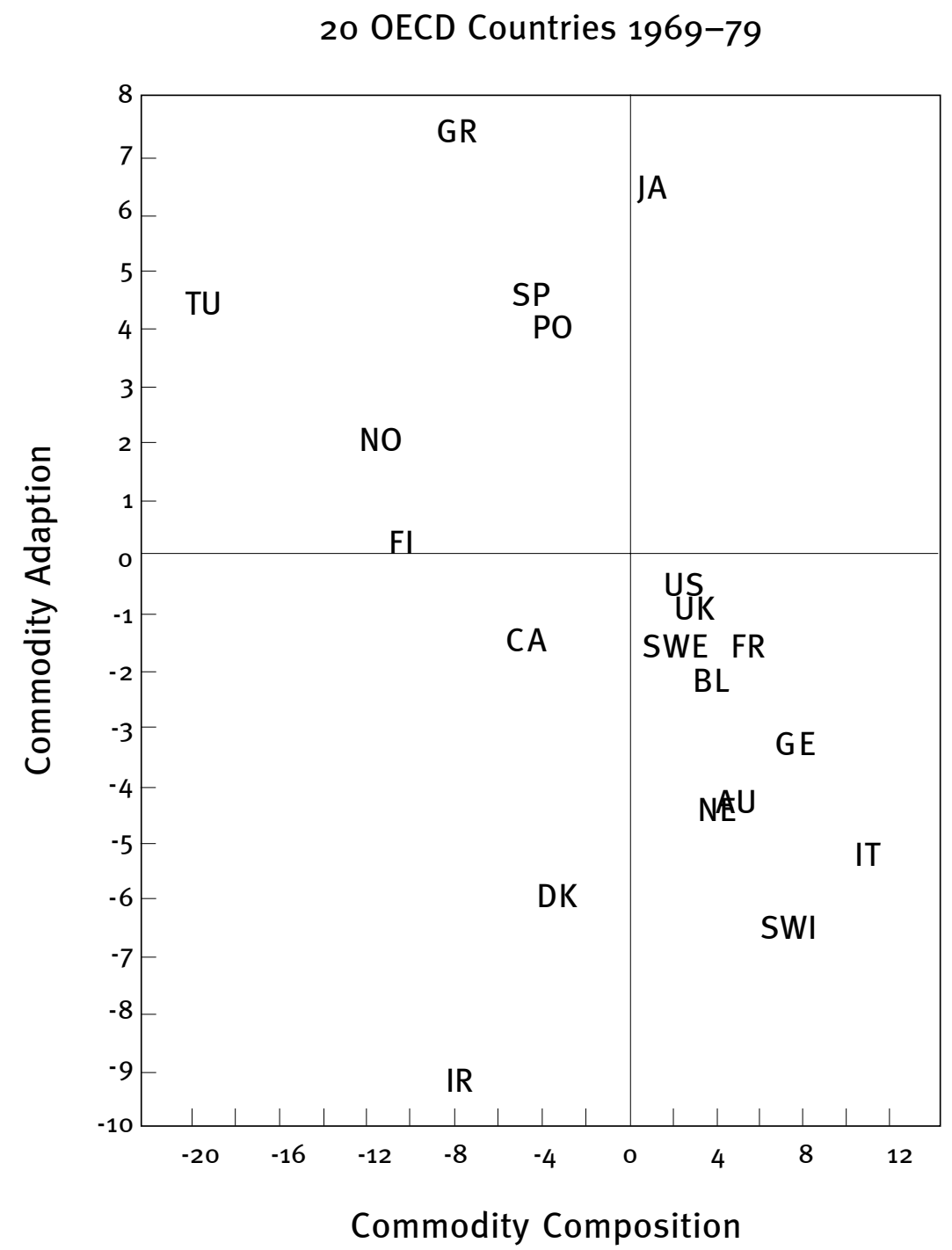




\section{Structure and Adaptability}

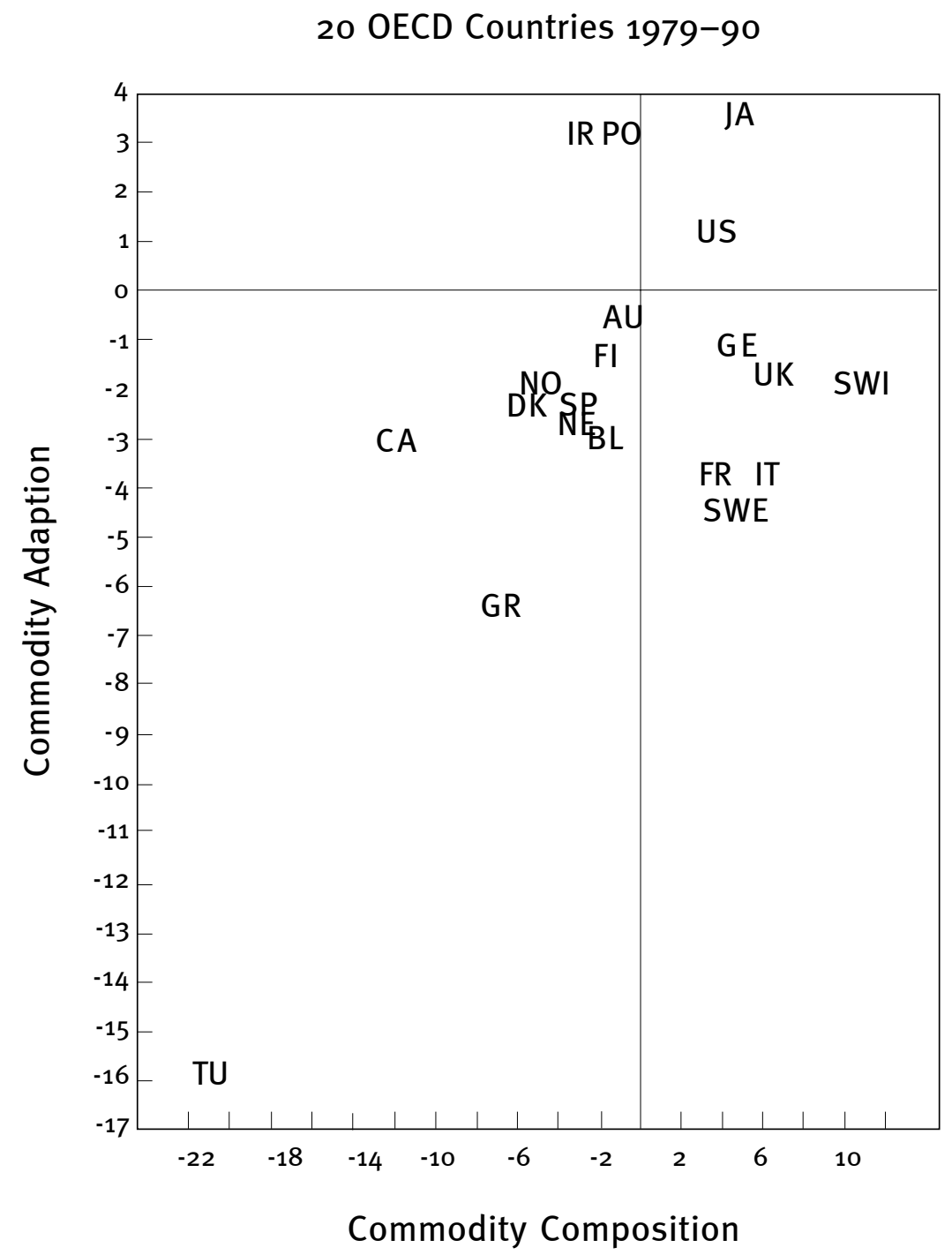

